and validation of a structured diagnostic psychiatric interview for DSM-IV and ICD-10. J Clin Psychiatry 1998; 59 (suppl 20): 22-33.

19 Hamilton M. Development of a rating scale for primary depressive illness. Br J Soc Clin Psychol 1967; 6: 278-96.

20 Klerman GL, Weissman MM, Rounsaville BJ, Chevron E. Interpersonal Psychotherapy of Depression. Basics Books, 1984.

21 Klerman GL, Budman S, Berwick D, Weissman MM, Damico-White J, Demby A, et al. Efficacy of a brief psychosocial intervention for symptoms of stress and distress among patients in primary care. Med Care 1987; 25: 1078-88.

22 Mossey JM, Knott KA, Higgins M, Talerico K. Effectiveness of a psychosocial intervention, interpersonal counseling, for subdysthymic depression in medically ill elderly. J Gerontol A Biol Sci Med Sci 1996; 51: M172-8.

23 Neugebauer R, Kline J, Bleiberg K, Baxi L, Markowitz JC, Rosing M, et al. Preliminary open trial of interpersonal counseling for subsyndromal depression following miscarriage. Depress Anxiety 2007; 24: 219-22.

24 Mundt JC, Marks IM, Shear MK, Greist JH. The Work and Social Adjustment Scale: a simple measure of impairment in functioning. Br J Psychiatry 2002 180: $461-4$.

25 Thase ME, Entsuah AR, Rudolph RL. Remission rates during treatment with venlafaxine or selective serotonin reuptake inhibitors. Br J Psychiatry 2001; 178: $234-41$.

26 McPartlin GM, Reynolds A, Anderson C. A comparison of once daily venlafaxine XR and paroxetine in depressed outpatients treated in general practice. Primary Care Psychiatry 1998; 4: 127-32.

27 Mynors-Wallis LM, Gath DH, Day A, Baker F. Randomised controlled trial of problem solving treatment, antidepressant medication, and combined treatment for major depression in primary care. BMJ 2000; 320: 26-30.

28 Kraemer HC, Wilson GT, Fairburn CG, Agras WS. Mediators and moderators of treatment effects in randomized clinical trials. Arch Gen Psychiatry 2002 59: $877-83$.

29 Pincus $\mathrm{T}$, Miles C, Froud R, Underwood M, Carnes D, Taylor S Methodological criteria for the assessment of moderators in systematic reviews of randomised controlled trials: a consensus study. BMC Med Res Methodol 2011; 11: 14

30 Sun X, Briel M, Busse J, You J, Akl E, Mejza F, et al. Credibility of claims of subgroup effects in randomised controlled trials: systematic review. BMJ 2012; 344: e1553.
31 Kraemer HC, Kupfer DJ. Size of treatment effects and their importance to clinical research and practice. Biol Psychiatry 2006; 59: 990-6.

32 Mynors-Wallis LM, Gath DH, Lloyd-Thomas AR, Tomlinson D. Randomised controlled trial comparing problem solving treatment with amitriptyline and placebo for major depression in primary care. BMJ 1995; 310: 441-5.

33 Brown C, Schulberg HC, Madonia MJ, Shear MK, Houck PR. Treatment outcomes for primary care patients with major depression and lifetime anxiety disorders. Am J Psychiatry 1996; 153: 1293-300.

34 Chilvers C, Dewey M, Fielding $\mathrm{K}$, Gretton V, Miller P, Palmer B, et al. Antidepressant drugs and generic counselling for treatment of major depression in primary care: randomised trial with patient preference arms BMJ 2001; 322: 772-5.

35 Bortolotti B, Menchetti M, Bellini F, Montaguti MB, Berardi D. Psychological interventions for major depression in primary care: a meta-analytic review of randomized controlled trials. Gen Hosp Psychiatry 2008; 30: 293-302.

36 Brown C, Schulberg HC, Prigerson HG. Factors associated with symptomatic improvement and recovery from major depression in primary care patients. Gen Hosp Psychiatry 2000; 22: 242-50.

37 You S, Conner KR. Stressful life events and depressive symptoms: influences of gender, event severity, and depression history. J Nerv Ment Dis 2009; 197: 829-33.

38 Salminen JK, Karlsson H, Hietala J, Kajander J, Aalto S, Markkula J, et al. Short-term psychodynamic psychotherapy and fluoxetine in major depressive disorder: a randomized comparative study. Psychother Psychosom 2008; 77: 351-7.

39 Hegerl U, Hautzinger M, Mergl R, Kohnen R, Schütze M, Scheunemann W, et al. Effects of pharmacotherapy and psychotherapy in depressed primarycare patients: a randomized, controlled trial including a patients' choice arm. Int J Neuropsychopharmacol 2010; 13: 31-44.

40 Brookes S, Whitely E, Egger M, Davey Smith G, Mulheran P, Peters T. Subgroup analyses in randomized trials: risks of subgroup-specific analyses; power and sample size for the interaction test. J Clin Epidemiol 2004; 57: 229-36.

41 Van HL, Schoevers RA, Dekker J. Predicting the outcome of antidepressants and psychotherapy for depression: a qualitative, systematic review. Harv Rev Psychiatry 2008; 16: 225-34.

\title{
100 Beckett and psychiatry
}

In Beckett we can detect themes of central importance to psychiatry. In both his novels and plays, his characters struggle with difficulties in memory, narration and vocalisation, with repetition, progression and ending, with failure, and with the pressure of incessant speech. Contemporary scholars are interested in psychiatric and neurological themes in Beckett's work, topics prominent in his own reading, as well as his own experience of psychoanalysis as Bion's analysand. Beckett's plays Not I and Rough for Theatre II have been used with clinicians and medical students to examine speech disorders, anxiety and role of case reports in clinical judgements. 